\title{
GMO'S - THE TRADE-OFFS BETWEEN ECONOMIC BENEFITS AND PERCEIVED HEALTH RISKS
}

\author{
Gheorghe $O R Z A N^{1}$ \\ Alexandra G. PRICOP ${ }^{2}$ \\ Madalina Maria MIHALACHE
}

\begin{abstract}
Food safety has become an important topic in the last decades as pesticides, chemical additives, hormones and other technological processed substances began to raise awareness among consumers, organizations and governments. At international scale it is being noticed an increasing concern that genetically modified food might have an unforeseen impact on human health. On the other hand, biotechnology has the ability to eliminate worldwide hunger and malnutrition in an efficient matter. Indirect costs that are associated with the production and adoption of genetically modified food as well as the potential to protect and conserve the environment need to be taken into account in the cost, benefit and perceived risk analysis. This paper describes the trade-offs between possible risks associated with genetically modified organisms and the economic benefits.
\end{abstract}

Keywords: genetically modified food, economic benefits, health risks, environment

JEL classification: Q5, Q13, Q18, O33, O44, P46

\section{Introduction}

Biotechnology use in agriculture has generated much controversy worldwide. Techniques used to improve livestock for food production, along with the various conservation methods have been in practice since humankind became to rely on agriculture for survival. Nowadays, we are facing the challenge of a fast growing world population that requires a higher food stock (Akumo et al., 2013). It is being predicted that the increase in the worldwide need for food will be 70 to $100 \%$ higher in the following years (World Bank, 2008). Therefore, "the future needs an agricultural system that produces about 50 percent more food to feed the world's 9 billion people by 2050 " (Holt-Giménez et al., 2015). This system should provide sufficient nutrition, raise income and employment, while providing environmental services and using resources in an efficient manner.

In the past, the need to deliver more food in a sustainable way has been neglected by bringing more land into agriculture and by finding new fish stocks. In the 21 st century, "the competition for land from other human activities makes this an increasingly unlikely and costly solution, particularly if protecting biodiversity and the public goods provided by natural ecosystems are given higher priority" (Godfray et al., 2010). A new pathway that would solve this problem is the genetic engineering of crops, in addition to plant breeding.

\footnotetext{
${ }^{1}$ Professor PhD, The Bucharest University of Economic Studies, Doctoral School of Marketing, 6 Romana Square, Bucharest, Romania.

${ }^{2} \mathrm{PhD}$ Candidate, The Bucharest University of Economic Studies, Doctoral School of Marketing, 6 Romana Square, Bucharest, Romania.

${ }^{3}$ PhD Candidate, The Bucharest University of Economic Studies, Doctoral School of Marketing, 6 Romana Square, Bucharest, Romania.
}

DOI: 10.29302/oeconomica.2018.20.1.5 
On the other hand, genetically modified food has given rise to major ideological and scientific concerns that are being echoed in the media and academic press for a long period of time

and has reached consumers in both rich and poor countries (Smale et al., 2009). Genetic modification processes are a solution for assisting food manufacturers and improving the storage capacity or nutritional value of food, although uncertainties, risks and benefits concerning this technology are widely disseminated to the food industry and to the consumers.

\section{What are genetically modified organisms}

Genes are changing by natural mutation on a daily basis, creating new biological variations. As Bawa and Anilakumar (2013) notes: "genetic modification is a set of gene technology that alters the genetic machinery of such living organisms as animals, plants or microorganisms". The process of combining genes from different organisms is being named "recombinant DNA technology" and the organisms that result are being referred to as "Genetically modified", "Genetically engineered" or "Transgenic" organisms (GMOs).

Genetically modified foods represent the outcome of a various set of "biotechnological procedures of recombining DNA", that provides the possibility to modify the genetic information of an organism by either incorporating genes from another organism, by suppressing genes from its own DNA or by rearranging genes already present (Schneider R. K., Schneider R. G., 2002). It "allows specific genes to be identified, isolated, copied and introduced into other organisms in much more direct and controlled ways [...] it also allows individual genes to be specifically switched off, through the antisense approach" (Jones, 1999), as seen in Figure 1.

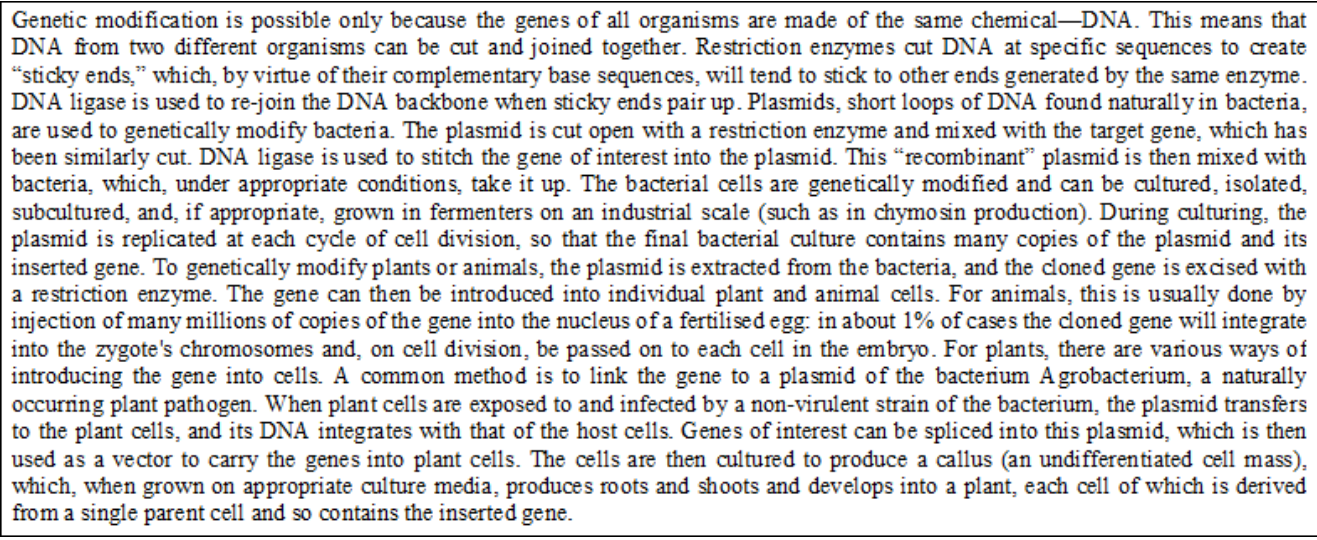

Figure 1. Manipulation of DNA [adapted from] "Genetically Modified Foods", by L. Jones, 1999, British Medical Journal 318, p.582.

As Hautvast and Van de Wiel (2001) notes: "genetic modification is the change of hereditary material by placing properties of one organism (micro-organism, plant, or animal) into another organism [...] genetically modified ingredients can be found in a large number of products like cookies, chocolate, sauces and cheese [...] furthermore, a great number of fruits and vegetables currently available in our supermarkets, like soy and maize, have been genetically modified" (Hautvast and Van de Wiel, 2001).

\section{GMO's distribution across countries}

The developing knowledge and understanding of cell function, heritability and genetic engineering that offers new opportunities to transfer and/or modify DNA from one organism to 
another has driven governments in many countries to match the food demand of the expanding population, as well as to provide efficient vaccines and pharmaceuticals, new food technologies and several other products that contribute to an improved standard of life (Akumo et al., 2013).

Despite their potential to bring added value to the food industry, genetically modified food products have been facing many barriers throughout the countries of the world from the regulatory and public acceptance point of view. While genetically modified crops have witnessed little resistance when introduced in the United States' food system, Europe, on the other side, has faced major opposition at the introduction of genetically modified organisms in each portion of the food chain (Hossain et al., 2003).

The idea of introducing genetically modified products in the food market has not been welcome due to health reasons. Despite the lack of clear research results that would imply negative outcomes of genetically modified food, the reasons behind their rejection is more or less of preventive nature (Akumo et al., 2013).

Although, considering their international distribution across countries in the past years, "thirteen countries grew genetically-engineered crops commercially in 2000, and of these, the U.S. produced the majority. In 2000, 68\% of all GM crops were grown by U.S. farmers. In comparison, Argentina, Canada and China produced only $23 \%, 7 \%$ and $1 \%$, respectively. Other countries that grew commercial GM crops in 2000 are Australia, Bulgaria, France, Germany, Mexico, Romania, South Africa, Spain, and Uruguay" (Whitman, 2000).

Argentina is also one of the biggest growers of genetically modified crops, mainly due to a complex combination of circumstances: ability to solve prevalent farmers' needs, economic and environmental factors, political support from agriculture officials and an early implementation of effective regulations. The advancements were possible through a rational, science-based and flexible regulatory framework that would certify that the genetically modified crops were safe for food, feed and processing (Burachik, 2010).

\section{Economic benefits of GMOs}

"Genetically modified (GM) plants, also called transgenic plants, are designed to acquire useful quality attributes such as insect resistance, herbicide tolerance, abiotic stress tolerance, disease resistance, high nutritional quality, high yield potential, delayed ripening, enhanced ornamental value, male sterility and production of edible vaccines" (Verma, 2013). "Another major goal for raising the GM plants is their application as bioreactors for the production of nutraceuticals, therapeutic agents, antigens, monoclonal antibody fragments biopolymers and so forth" (Verma, 2013).

Given that the global population has reached the 7 billion mark in 2011 (Unfpa.org, 2017), ensuring the sufficient food supply is becoming more and more challenging. Therefore, as Whitman (2000) notes: genetically modified food assures to match this need in numerous ways:

- Pest resistance, resulting in reduced costs of crops delivery to the markets by eliminating the costs implied by the application of chemical pesticides;

- Herbicide tolerance. Removing weeds by either physical means such as tilling or by spraying large quantities of different herbicides are time-consuming and expensive processes, also having the potential to cause environmental harm. Therefore, plants that are genetically engineered in order to be resistant to powerful herbicides could help prevent environmental harm, at a lower cost;

- Disease resistance;

- Cold tolerance. By associating an antifreeze gene from cold water fish with the original plant's DNA, some are able to tolerate cold temperatures that would normally destroy genetically unmodified seedlings; 
- Drought tolerance/salinity tolerance. Larger areas of land are being used for construction purposes in detrimental of agricultural use. Hence, in order to meet the growing demand,locations previously unsuited would need to be taken into account to cultivate crops. Genetically modified crops could be cultivated in such areas, leading to scale economies at the production level;

- Pharmaceuticals. Edible vaccines in crops are being the subject of many researches that aim to reduce distribution costs of traditional vaccines;

- $\quad$ Phytoremediation. Some genetically modified plants are being specifically engineered to clean up heavy metal pollution from contaminated soil in a cost-effective way (Whitman, 2000).

A study done across China concludes that "the economic gains from GMO adoption are substantial [...] In the most optimistic scenario [...] the welfare gains amount to an additional annual income of about 5 billion US\$ in 2010", that representing a very high amount for emerging economies (Huang et al., 2003).

\section{Perceived health risk}

The attitudes towards genetic modified technologies are continuously evolving as consumers' perception of health risks and benefits are dynamic processes, under the influence of a series of factors. As Costa-Font et al. (2008) notes: "knowledge about a specific GM product and the underlying production process become essential in order to shape attitudes". The more knowledge of genetic modification technology people gather, the more supportive to GM applications they are. Besides this, studies conducted in Europe and Japan presents evidence that consumers are willing to take the risks of consuming genetically modified foods only if these products are offered at significant cost savings over non-GM foods, despite their lack of knowledge (Curtis et al., 2004).

If there isn't a positive direct correlation between biotechnology and consumers benefits, the main drivers of genetically modified foods approval are the public attitudes towards private and public institutions associated with biotechnology (Hossain et al., 2003). Consumers' knowledge of basic biotechnology as well as the trust and confidence in authorized institutions are of major importance for wide acceptance of food biotechnology.

The major health risk concerning genetically modified foods is that they can cause allergic reactions. Certain proteins in milk, wheat, eggs, fish, peanuts, tree nuts and shellfish cause over $90 \%$ of total food allergies (Schneider R. K., Schneider R. G., 2002). Besides this, another perceived risk makes reference to the environment. "Liberals and suburban consumers are often more concerned about environmental issues and are more apprehensive of the potential negative implications of agricultural biotechnology for the environment" (Hossain et al., 2003). "It is thought that genetically modified plants could be harmful to the environment by depleting soil microorganism which are very important for soil fertility and influence the micro-environments of other organisms" (Akumo et al., 2013). One of the most impactful risks associated with genetically modified organisms encloses their potential impact on "non-target soil microorganisms which plays a fundamental role in crop residues degradation and in biogeochemical cycles" (Akumo et al., 2013).

As Siegrist (2000) notes, in comparison with other food perils, genetically modified food is being perceived as a moderately severe and unknown risk. Moreover, a significant distinction at the perceptual level was being noticed among society members between genetically modified plants and animals (plants being preferred to animals) foods and drugs (drugs being preferred to foods). Besides these, factors such as power, alienation, status and trust determine the acceptance and perceptions of risk. "Trust in institutions or persons doing genetic modification research or using modified products is the most important factor influencing perception of gene technology. Trust has an impact on perceived risk as well as on perceived benefit" (Siegrist, 2000). 
In a study done in United States and in all European countries, Gaskell et al., (1999) has concluded that Europeans better accept genetic testing than genetically modified foods, in comparison with people in the United States, that were highly more in favour of genetically modified foods.

Large series of studies have investigated consumer acceptance of GM foods in the United States and Europe in an economic framework and the results suggest that "when no direct benefit is provided to consumers, fear or concern over biotechnology dominates purchasing behaviour, as most consumers are willing to pay premiums for 'GM-free' products over foods with GM ingredients. On the other hand, Lusk et al. (2004) has concluded that some consumers could be willing to pay premiums for genetically modified foods when presented with specific benefits provided by biotechnology.

Consumer attitudes are driven by three factors: risks and benefit perceptions associated with genetically modified food, individual values and attributes, knowledge and its relation with the personal value system (Costa-Font et al., 2008).

\section{Conclusion}

More and more questions are being raised on the effects that genetically modified foods have on people's health, the environment and the overall economy. Besides, genetically modified food has the ability to eliminate worldwide hunger and malnutrition in an efficient matter.

The key drivers of consumers' attitude towards genetically modified food are the trust and confidence in public and corporate institutions. A significant effect on how individuals respond to new information regarding genetically modified foods is being produced by their primary attitude towards biotechnology. More than that, the acceptance of genetically modified products is in a strong direct connection with the perceived risk and the perceived benefit.

Although considerable uncertainty is surrounding the field of genetic modification and the innovations in this area of research, GMO's could have a crucial role in shaping the future of agriculture. The nature of their impact, along with the size and distribution of involved benefits and risks will be defined to a large extent by the types of genetically modified foods that will be brought to the market. In this context, the regulations, safety testing, international policy and food labelling are a great challenge for governments, health and environmental organisations, aiming at preserving the biodiversity, the public good and also aiming for sustainable economic development.

The political regulations and the consumer's shopping behaviour will determine how genetic technology will be used in the future, in the food sector.

\section{References}

1. Akumo, N.D., Riedel, H., Semtanska, I. 2013. Social and Economic Issues - Genetically Modified Food, Chapter 10. Agricultural and biological sciences, food industry, I. Muzzalupo;

2. World Bank (2008). World Development Report 2008: Agriculture for Development (World Bank, Washington, DC.

3. Holt-Giménez, E., Williams, J., Hachmyer, C. 2015. The World Bank Group's 2013-15 Agriculture for Action Plan: A Lesson in Privatization, Lack of Oversight and Tired Development Paradigms, Oakland, CA.

4. Godfray, H. C. J., Beddington, J. R., Crute, I. R., Haddad L., Lawrence, D., Muir, J. F., Pretty, J., Robinson, S., Thomas, S. M., Toulmin, C. 2010. Food Security: The Challenge of feeding 9 billion people.

5. Smale, M., Zambrano, P., Gruere, G., Falck-Zepeda, J., Matuschke, I., Horna, D., Nagarajan, L., Yerramareddy, I., Jones, H. 2009. Measuring the Economic Impacts of Transgenic Crops in Developing Agriculture during the First Decade. Approaches, Findings and Future Directions. Food Policy Review 10, IFPRI, Washington: USA. 
6. Bawa, A. S., Anilakumar, K. R. 2013. Genetically Modified Foods: Safety, risks and public concerns-A Review. Journal of Food Science and Technology 50(6).

7. Schneider, R. K., Schneider, R. G. 2002. Genetically modified food. Institute of Food and Agricultural Sciences, University of Florida.

8. Jones, L. 1999. Science, medicine, and the future: Genetically Modified Foods, BMJ : British Medical Journal 318 (7183): 581-584, [online] available at https://www.ncbi.nlm.nih.gov/pmc/articles/PMC1115027/ [Accessed at 8 April 2017].

9. Hautvast, J., Van De Wiel, J. (2001). Biotechnologie en voedsel [Biotechnology and food]. Niaba (Ed.), Biotechnologie: Een plaats in de samenleving;

10. Hossain, F., Onyango, B., Schilling, B., Hallman, W., Adelajal, A. 2003. Product attributes, consumer benefits and public approval of genetically modified foods. International Journal of Consumer Studies, (27).

11. Whitman, D. 2000. Genetically Modified Foods: Harmful or Helpful, CSA, [online] available at: https://biomed.brown.edu/arise/resources/docs/GM\%20foods\%20review.pdf [Accessed at 8 April 2017].

12. Burachik, M. 2010. Experience from use of GMO's in Argentinian agriculture, economy and enviroment. New Biotechnology (27).

13. Verma, S. R. 2013. Genetically Modified Plants: Public and Scientific Perceptions, Hindawi Publishing Corporation ISRN. Biotechnology Volume, Article ID 820671, http://dx.doi.org/10.5402/2013/820671.

14. Unfpa.org. 2017. World population trends | UNFPA - United Nations Population Fund. [online] Available at: http://www.unfpa.org/world-population-trends [Accessed 1 May 2017].

15. Huang, J., Hu, R., van Meijl, H., van Tongeren, F. 2003. Economic Impacts of Genetically Modified Crops in China. Proceedings of the 25th International Conference of Agricultural Economists.

16. Costa-Font, M., Gil, J. M., Traill, W. B. 2008. Consumer Acceptance, Valuation Of And Attitudes Towards Genetically Modified Food: Review And Implications For Food Policy. Food Policy 33.2.

17. Curtis, K. R., McCluskey, J. J., Wahl, T. I. 2004. Consumer Acceptance of Genetically Modified Food Products in the Developing World. AgBioForum, (7).

18. Siegrist, M. 2000. The influence of trust and perceptions ofrisks and benefits on the Acceptance of Gene Technology. Risk Analysis, XX, (2).

19. Gaskell, G., Bauer, M. W., Durant, J., Allum, N. C. 1999. Worlds Apart? The Reception of Genetically Modified Foods In Europe And The U.S. Science 285.5426.

20. Lusk, J. L. 2004. Effect of Information about Benefits of Biotechnology on Consumer Acceptance of Genetically Modified Food: Evidence From Experimental Auctions In The United States, England, And France. European Review of Agriculture Economics 31.2. 